\title{
The LaW Society of Alberta in the MatTer OF THE CONDUCT OF KENNETH ROBERT SOCKETT, Q.C.: A BRIEF COMMENTARY ON THE RESPONSIBILITIES and Perversions of Self-GovernanCe
}

\author{
F.C. DECOSTE
}

If it be true ... that the condition of the legal profession is an index of civilization, then its learning. its integrity, its character, are matters of public concernment.

\section{- David Dudley Field'}

Mr. Sidon ... worked on the basis that he could trust the lawyers providing legal services.

\section{- Report of the Hearing Committee ${ }^{2}$}

\section{Professor, Faculty of Law, University of Alberta.}

"Study and Practice of the Law" in A.P. Sprague, ed., Speeches, Arguments, and Miscellaneous Papers of David Dudley Field, vol. 1 (New York: D. Appleton, 1884) 484 at 487.

Law Society of Alberta, Report of the Hearing Committee in the Matter of the Legal Profession Act and in the Matter of a Hearing Regarding the Conduct of Kenneth Robert Sockett. Q.C., a Member of the Law Society of Alberta at 7 [hereinafter Report] (Michael Sidon, a witness for the Law Society at the Sockett hearing, is the officer of the Department of Indian Affairs and Northern Development, Edmonton, responsible for administering trust monies held by the federal government for the benefit of Treaty Six First Nation minors: see Report at 8; and "Agreed Statement of Facts," Report, App. No. 1 (Exhibit 130) at 2. It was to Sidon that Sockett rendered the statements of account for payment for legal work and disbursements that were the cause and object of the citations and the hearing). The Hearing Committee [hereinafter the Committee] was comprised of Charles Gardner, Q.C., Morris Taylor, lay member, and James Peacock, Q.C., convened on 6 May 2002, and heard evidence and argument for five days through to 10 May 2002. when it rendered its decision. The decision was proclaimed by the Law Society of Alberta in a Notice of Suspension dated 15 August 2002. The Hearing Committee reconvened on $18 \mathrm{July}$ 2002 to hear an application made on behalf of Sockett, which it dismissed, to hear fresh evidence and to stay the suspension. The Committee released its Report in the matter on 6 November 2002. Between the date the Committee rendered its decision and the date it issued its Report, Sockett complained publicly about what he took to be the Committee's delay in issuing the Report (see "Disciplined lawyer in limbo: Five months after ruling, no reasons issued" Edmonton Journal (2 November 2002) B5). During this period, he also announced, again publicly, his intention to appeal as allowed by s. 75 of the Legal Profession Act. R.S.A. 2000. c. L-8 (see "Wetaskiwin lawyer begins suspension, continues appeal" Edmonton Journal (19 July 2002) A7). As at 20 November 2002, the Law Society had not set down the date of hearing of Sockett's appeal $(20$ November 2002, telephone communication from Law Society of Alberta concerning the status of Sockett's appeal).

By way of context, it should be added that, though Sockett is the sole proprietor of his firm, Sockett and Associates, located in Wetaskiwin, Alberta, he is neither the first nor the last member of his firm to be subject to disciplinary proceedings as regards the subject matter of the main charges against him. On 5 November 2001, George Guy Watson - who, prior to joining Sockett and Associates. was consulted by Sockett on how to access First Nation minor trust funds (Report at 12) - was suspended for nine months "for failing to be candid to the Government of Canada by falsely describing his account relating to legal fees respecting his client" (as stated in the "Notice of Suspension": see Law Society of Alberta, online: <www.lawsocietyofalberta.com/ media/2001 suspentions.asp $>$. In a proceeding concluded 15 November 2002, Brian P. Marty stood charged of "defrauding the Federal Government of Canada" and "of misappropriat[ing] trust funds 
He pocketed hundreds of thousands of dollars. That benefited his business and him personally. I can't think of how that is different.

- Mel Buffalo, President of the Indian Association of Alberta ${ }^{3}$

\section{INTRODUCTION}

We lawyers think, of course, as did he, that Field's conditional is rhetorical flourish, and that the law we practice is indeed critical to civilized life. And we like to think that others - not only clients, but related parties and the citizenry at large - can trust us, as did Sidon (and, apparently, until recently, Buffalo as well), faithfully and competently to perform our lawyerly tasks. We are not just right in thinking in these ways - though, certainly, we are right - but we are also, by the force and reason of our office, consigned to thinking so. The rule of law imposes these thoughts upon us, not as an occasion of hubris or conceit, ${ }^{4}$ but as an instruction to conceive of ourselves as responsible to and for the public and, consequently, as a demand that we perform the host of obligations of service that follows from that professional self-conception. ${ }^{5}$

The rule of law is the threshold to civilized life, to a life of political equality and of political and civil liberty, because absent the constraint on political and social power

received from the Government of Canada" (see Law Society of Alberta, online: <www.lawsociety ofalberta.com/media/Hearings.asp>: "Lawyers face hearings over handling of native youth trust funds" Edmonton Journal (9 November 2002) A6: "Law Society Hearing: Lawyer admits billing native minors' trust funds for unrelated legal work - Faces disbarment over allegations he defrauded the federal government" Edmonton Journal (12 November 2002) A6; and "Wetaskiwin lawyer faces withering cross-examination in trust funds case - Law society hearing for Marty" Edmonton Journal (15 November 2002) B4). Nor is Sockett's the only firm against whose members citations regarding matters of this sort have arisen. On 16 and 17 December 2002, a Hearing Committee will convene to consider, inter alia. charges against Glen E. Allen of Deckert Allen. Wetaskiwin. that he "deceived the Federal Government in five instances with respect to the purpose and use of tunds requisitioned from the Federal Government for native minors." and that he "wrongfully converted money held in trust for a young person" (see Law Society of Alberta. online: <www.lawsocietyofalberta.com/media/Hearings.asp >). On 3 February 2002, another committee will convene to hear citations against Peter C. Hanington of Hanington Tumer. Edmonton. that he "deceived the Federal Government in five instances with respect to the purpose and use of trust funds requisitioned from the Federal Government for native minors" (e-mail communication from Law Society of Alberta of wording of its citation against Hanington (20 November 2002)).

At the time of the writing of this comment, late November 2002. the decision in Marty's case had not been rendered. nor had the hearings of the citations against Allen or Hanington been convened.

"Law Society accused of 'protecting their own' in Sockett case" Edmonton Journal (8 November 2002) A6. According to this report, Buffalo went on to say that "the Sockett case has slaken native people's trust in the law society's ability to fairly and objectively regulate its members." Though. as Simpson reminds us. lawyers have very often mistaken their status as a cause for selfcongratulation and moral complacency: see A.W.B. Simpson, Leading Cases in the Common Law (Oxford: Clarendon Press, 1995) at 228.

" See. e.g.. F.C. DeCoste. "Towards a Comprehensive Theory of Professional Responsibility" (2001) 50 U.N.B.L.J. 109. 
that it alone provides, equality and liberty must needs fall prey to strength and stealth. ${ }^{6}$ A free and independent and, therefore, self-governing legal profession is an institutional requirement and consequence of the rule of law. ${ }^{7}$ The calculus to this result is simple enough: the rule of law state is a moral agent whose authority depends upon its making good its moral point, namely, the constraint of power - its own political power and private social power; for the state to meet this obligation its own powers must be cabined, and to be cabined, those powers must be separated and, as put by Montesquieu, "counter-balanced" one against the other. ${ }^{8}$ This institutional requirement of the separation of powers founds not only the independence of the judicial branch from the executive and the legislature, but the freedom and independence of the society of lawyers from which the judiciary is drawn and of which it remains, in head and heart, from political power. ${ }^{9}$ Thus is the privacy of the profession authorized: selfgovernance exists to serve the very public purpose of governance by rule of law. It is by virtue of that purpose alone that professional monopoly is saved from self-interest and rendered a principle of good government, and that professional membership is made out a status and not a mere license.

The obligations of self-governance, and the conditions of their proper execution, arise from and depend upon the rule of law values that give birth and sustenance to both. The constitutive obligation of self-governance is membership: the society of lawyers alone may award the status of barrister and solicitor. That this is so makes being a lawyer a privilege for which one prays and not a entitlement which one claims. ${ }^{10}$ Nor only that: the award of that privilege may only properly depend upon conditions that the society of lawyers must itself identify. Hence the defining obligation of selfgovernance: articulation and then application of the conditions of membership, both its award and its continuance, is the central task and obligation of lawyers collectively through their societies. And it is their accomplishments in collectively making good this undertaking that provides both measure and principle to their independence.

The public promise and purpose of self-governance requires that lawyers both articulate and apply the conditions of membership in a fashion consonant with the rule

" For views of this necessity see F.A. Hayek. The Constitution of Liberty (Chicago: University of Chicago Press, 1960). especially at Part Il, "Freedom and the Law”; T.R.S. Allan, Constitutional Justice: A Liberal Theory of the Rule of Law (Oxford: Oxford University Press, 2001); and F.C. DeCoste. "Redeeming the Rule of Law" (2002) 39 Alta. L. Rev. 1004.

7 That this is so grants law societies constitutional status, and makes of legislation such as the Legal Profession Act (R.S.A. 2000, c. L-8) an acknowledgement and requirement of constitutionalism. Not only. therefore, does the status of the society of lawyers not finally depend upon such statutory instruments, but that status could only properly be altered through changes to such instruments on two grounds: in the event of a political revolution that changed the terms and conditions of political and legal life, or in the event that the society of lawyers shows itself either unable or unwilling to perform its constitutional obligations of self-governance.

* A.M. Cohler et al.. eds.. Montesquiew: The Spirit of the Laws (Cambridge: Cambridge University Press, 1989) at 182 .

For the details of this calculation see F.C. DeCoste. On Coming to Lati: An Introduction to Law in Liberal Societies (Markham: Butterworths. 2001) at 162-70.

i" As famously put by Judge Cardozo. "membership in the bar is a privilege burdened with conditions" (In the Matter of Rouss, 221 N.Y. 81 at 84 (1917)). 
of law. In the first place, they must define the conditions properly; and consonant with the understanding that being a lawyer is a status and a privilege, they must view qualification in terms of fitness for office and not in terms of criteria for license. So viewed, membership depends upon what may be termed the three Cs of professional life - competence, character, and conduct. Second, fitness must be assessed as regards the office of lawyer simpliciter, and not as regards any speciality of practice (which understanding would be proper were being a lawyer a matter to be licensed and not a status to be conferred); and the award must, therefore, be the same to all. This condition makes the society of lawyers a society of equals, pledged not only in purpose, but in character as well, to the equality under and through law that is the rule of law. Finally, in their deliberations about fitness in these senses, lawyers must conform to those peculiar requirements and virtues of the rule of law - namely, governance through rules, due process, transparency, and, where sanction is due, proportionality.

With these understandings and requirements in mind, it is my purpose in this comment to make two arguments as regards the Law Society of Alberta's conduct of and decision in the Sockett matter. I shall argue firstly that the Committee's decision in the matter is wrong as an exercise in responsible self-governance. I shall then argue, by way of a brief conclusion, that this particular mistake, together with popular and other reaction to the decision in this matter as well as judicial comment as regards the conduct of the Law Society of Alberta in other matters, threaten a more systemic failure of self-governance to which the Law Society of Alberta is duty-bound to attend. I shall proceed as follows: after stating and situating the citations against Sockett and summarizing the Committee's findings regarding each, and its findings of fact and law more generally, I shall deal with Sockett's "defence" and criticize the Committee's treatment of those arguments and its reasons for decision.

\section{The Citations}

Mr. Sockett stood accused of the following seven citations:

Citation \# I: IT IS ALLEGED that you did, by deceit, falsehood or other fraudulent means defraud the Federal Government of Canada, by submitting statements of accounts to be paid from trust funds of minors, which accounts included payments to you for disbursements which were not proper, which funds you improperly diverted to others, and that such conduct is conduct deserving of sanction.

Citation \# 2: IT IS ALLEGED that you did misappropriate trust funds received from the Government of Canada, and that such conduct is conduct deserving of sanction.

Citation \# 3: IT IS ALLEGED that you did. by deceit, falsehood or other fraudulent means defraud the Federal Government of Canada, by submitting statements of accounts to be paid from trust funds of minors, which accounts were for legal services that you did not provide. and that such conduct is conduct deserving of sanction.

"Quotes because "explanation" might be a more proper description. I shall, nonetheless, deal with his responses to the citations of fraud against him as if they were defences properly so called. 
Citation \# 4: IT IS ALLEGED that you did misappropriate trust funds received from the Government of Canada, and that such conduct is conduct deserving of sanction.

Citation \# 5: IT IS ALLEGED that you did, by deceit. falsehood or other fraudulent means defraud the Federal Government of Canada, by submitting statements of accounts to be paid from trust funds of minors, which accounts were for your representation of parties other than the referenced minor. and that such conduct is conduct deserving of sanction.

Citation \# 6: IT IS ALLEGED that you did misappropriate trust funds received from the Government of Canada, and that such conduct is conduct deserving of sanction.

Citation \# 7: IT IS ALLEGED that by embarking on a scheme of enticing clients by making payments of money to them which would not otherwise be accessible to them, you engaged in conduct which would tend to bring the legal profession into disrepute, and that such conduct is conduct deserving of sanction. ${ }^{12}$

The minors were all members of Treaty Six Bands located at or near Hobbema, Alberta. The trust monies at issue are a creature of federal law governing First Nation minors. As put by the parties in an "Agreed Statement of Facts,"

The minors of these Indian Bands are entitled to per capita distributions from their respective band capital accounts. The share of the per capita distribution payable to the Minor is deposited into the Consolidated Revenue Fund for the Government of Canada as defined by the Financial Administration Act. A separate record/account is kept for each Native Minor. The funds so held "can be viewed as monies over which the Minister has a trust like duty". 13 The share of the per capita distribution payable to the Minor is held until the Minor becomes 18 years of age. The Minister may pay all or part of any money administered by the Minister under Section $52^{14}$ that belongs to an infant child of an Indian to a parent or person who is responsible for the care and custody of the child or otherwise apply all of part of that money if

a) the Minister is requested in writing to do so by the parent or the person responsible: and

b) in the opinion of the Minister the payment or application is necessary or proper for the maintenance, advancement or other benefit of the child. ${ }^{15}$

As mentioned, ${ }^{16}$ Michael Sidon, of the Department of Indian Affairs and Northern Development, Edmonton, was during the period relevant to the citations against Sockett, the Minister's delegate with respect to these monies for Treaty Six minors. In that capacity, Sidon was responsible for "hundreds of accounts for the Treaty Six Bands Members alone." 17

12. Report, supra note 2 at 2-3.

13 Though the "Agreed Statement of Facts" does not make it clear, the "Minister" here refers to the Minister of Indian Affairs and Northern Development.

is Again. for clarity. S. 52 of the Indian Act, R.S.C. 1985, c. 1-5.

is Report, supra note 2. "Agreed Statement of Facts." App. No. I (Exhibit 130) at 1.

i1. Supra note 2.

1" Report, supra note 2 at 11 . In Alberta, there are apparently "thousands of minors' trust accounts ... totalling in excess of $\$ 100,000,000.00 "$ (ibid. at 10-11). 


\section{The Committee's Findings}

The Committee heard evidence from twelve witnesses. The Law Society, represented in the matter by Janet Dixon, called two witnesses: Glenn Anderson, C.A., Law Society staff auditor; and the aforementioned ${ }^{18}$ Sidon of the Department of Indian Affairs and Northern Development. Sockett, who was represented by Robert Davidson, Q.C., ${ }^{19}$ called ten witnesses: Sockett himself; five witnesses ${ }^{20}$ who, though none of them "had personal knowledge of the events,"21 were heard by the Committee on grounds that the "contextual evidence"22 they could proffer as regards "the social conditions existing on the reserves" 23 would be "helpful"24 "in the context of matters"25 before it; three character witness; ${ }^{26}$ and a legal assistant employed at Sockett's firm. ${ }^{27}$

\section{A. OF FACT}

For convenience, I shall summarize the Committee's findings of fact under five headings: (1) the extent and quantum of Sockett's conduct; (2) the modus operandi of Sockett's conduct with examples; (3) other practices of Sockett in these matters; (4) Sockett's admissions; and (5) Sockett's motivation.

\section{THE EXTENT AND QUANTUM OF SOCKETT'S CONDUCT}

The Committee found that, during the two years preceding 2000 - the period of the Law Society investigation - Sockett accessed the trust funds of First Nations minors on ninety-seven occasions that qualified under the citations and that these transactions involved $\$ 440,000$, of which he retained $\$ 217,000$ in legal fees. ${ }^{28}$ It also found that, in 1999, 12.39\% of Sockett's billings were in relation to First Nation minors' trust accounts. $^{29}$

Supra note 2.

And later when the Committee reconvened to hear Sockett's fresh evidence and stay of suspension application, by Brian Beresh, Q.C..

R.C.M.P. Constable Allan Shepherd; Ernie Schwartzat, a former band administrator; Denis Hardy, a parole officer; Robert Silverthorn, a band education consultant; and Lucy Johnson, a native court worker. All but Johnson also offered character evidence.

Report, supra note 2 at 5.

Ibid. at 20.

Ibid. at 5 .

Ibid. at 20.

Ibid. at 11 .

All lawyers: Brian Chatwin, Q.C.; Phil Lister, Q.C.; and Ed Boomer. Four of the "contextual evidence" witnesses also offered character evidence: see supra note 20.

Namely, Laurie Sims. The Committee also received the affidavit evidence of Stacy Bailer, another employee of Sockett and Associates.

Report, supra note 2, App. No. 3, "Agreement re Similar Particulars," (Exhibit 151 including tables); and a telephone communication with Law Society (20 November 2002) confirming both the number of incidents and their monetary value. overall and as profit for Sockett.

Ibid. at 16-17. 


\section{THE MODUS OPERANDI OF SOCKETT'S CONDUCT WITH EXAMPLES}

The Committee found that "there were three types of situations where the Member assisted a minor in accessing the minor's trust funds":

(a) the Member was retained to represent a minor in a criminal matter, and either during the course of the matter or at its conclusion, gave the minor funds that he had received from the trust fund in payment of disbursements described in either a previously rendered or subsequently rendered statement of account as either "ancillary disbursements" or "anticipated disbursements" (Citations 1 and 2);

(b) the Member was approached by a minor to access the trust fund for a certain purpose and the Member rendered a statement of account for disbursements in connection with representing the minor in the matter when, in fact, the only service provided was to access the trust fund and the sole purpose of the statement of account was to obtain sufficient funds to give to the minor and to pay the Member's fee for providing this service (Citations 3 and 4); and

(c) the Member was approached by a minor or a member of the minor's family to access the minor's trust fund to pay the legal fees for services rendered by the Member in connection with the legal representation of someone other than the minor and the statement of account did not disclose that the legal fees were for the representation of someone other than the minor (Citations 5 and 6$)^{30}$

These situations are instantiated on various facts throughout the Report. For example: Sockett accessed a minor's trust fund for legal fees for a change of name for a minor when he knew the money requisitioned was to be used to purchase an automobile; ${ }^{31}$ on at least one occasion, where no legal service other than accessing the account was rendered, his fee "amounted to $35 \%$ of the amount accessed"; 32 in another instance, Sockett accessed trust funds for legal fees for a minor when in fact the funds were used to pay the fees owed to Sockett by the minor's brother; ${ }^{33}$ and, in yet another instance, Sockett accessed funds for legal services to a minor when in fact the funds were used to pay for services rendered to the minor's boyfriend. ${ }^{34}$

\section{OTHER Practices OF SOCKeTt IN THESE MATTERS}

The Committee found that it was common for Sockett to have a minor and the minor's parent or guardian sign an authorization for access to trust funds in which the amount to be accessed was left blank; ${ }^{35}$ and that Sockett's practices began with

Ibid. at 4-5.

Ibid. at 19.

lbid. at 18. See also at 9 (Sockett charged $\$ 400$ in legal fees solely for accessing a minor's account for the sum of $\$ 1,400$, a charge of $28 \%$ ).

lbid. at 10.

lbid. at 17-18.

lbid. at 18 (Sockett testified that, "once the amounts were filled in it was his practice to tell the minor or parent or guardian what had been filled in and to show them the completed authorization by having them come to his office"). 
accessing trust funds to pay for legal services (and disbursements) rendered by him to the minor whose account was being accessed, progressed to including cash advances to minors or to their parents or guardians in the statement of accounts for legal fees tendered to the Department of Indian Affairs and Northern Development, and culminated with accessing trust funds "only for the purpose of providing cash advances to trust fund beneficiaries and, occasionally, family members." ${ }^{\text {}} 6$

\section{SOCKETT'S ADMISSIONS}

The Committee found Sockett to have made a host of admissions, including that, "in conducting himself as he had in these matters, he had breached his oath as a barrister and solicitor" ${ }^{37}$; and that in each of the three types of situations, "the requisition or the statement of account submitted to the Department of Indian Affairs and Northern Development did not factually describe either the services rendered or intended to be rendered or the disbursements incurred or intended to be incurred." ${ }^{38}$

\section{SOCKETT'S MOTIVATION}

The Committee accepted Sockett's "evidence that his motivation for his actions was to help the minors involved," 39 and found, as well, that he "knew his actions were not lawful." ${ }^{240}$

\section{B. OF LAW}

The Committee made the following four findings: first, that in committing the conduct alleged in citations 1, 3, and 5, Sockett had defrauded the Government of Canada and, in so doing, had committed conduct deserving of sanction; ${ }^{41}$ second, that his "misconduct was a violation of the fundamental principles governing a lawyer's conduct", ${ }^{42}$ third, that "an appropriate sanction for findings of guilt with respect to Citations 1, 3 and 5 is that the Member be suspended for a period of eighteen months and that he pays a fine in the amount of $\$ 5,000$ for each Citation plus the actual costs of the hearing"; ${ }^{43}$ and fourth, that "there are reasonable and probable grounds to

"Ibid. at 13 (as regards the "family" qualification, see supra note 34 and accompanying text). Sockett testified that the latter two of these practices ended in June or July 2000, when in a conversation with Sidon he declared that "enough is enough" and that "he couldn't continue to stand in the shoes of the parents of these minors." The Committee does not appear to have accepted this evidence of renunciation and abandonment. As put by the Committee, "this evidence was in sharp contrast with the evidence given by Mr. Sidon and the Member's recollection of this conversation with Mr. Sidon was not put to Mr. Sidon during cross-examination" (ibid. at 15-16).

$17 \quad$ lbid. at 19.

ix Ibid. at 5. See also at 13, 17-18.

3.) Ibid. at 24. See also at 26: "the Committee accepts the Member's evidence that his primary motivation in acting in the manner in which he did was to assist those minors on [whose] behalf he sought to access funds."

Ibid. at 25 .

Ibid. at 22, 24, 26.

Ibid. at 29.

Ibid. at 27. 
believe that the Member may have committed a criminal offence and, accordingly, [the Committee] directed that a copy of the hearing record be forwarded to the Minister of Justice and the Attorney General for Alberta, pursuant to Section 78(5) of the Legal Profession Act." ${ }^{, 44}$ The Committee dismissed Citations 2, 4, and 6, because in its view "the conduct alleged in [those citations] is, in effect, subsumed by the fraudulent conduct described in Citations 1, 3, and 5" and, "having found the Member guilty of Citations 1,3 , and 5 , it is not necessary to make findings with respect to Citations 2 , 4 , and 6." 45 It also dismissed Citation 7 on the ground that it was not made out on the evidence, in part because of what the Committee took to be Sockett's motivation, in part because, given that motivation, "there was no need for entic[ing]" those who "sought the Member's assistance in gaining access to their trust funds," and in part because Sockett "declined" to assist "many more" than he assisted. ${ }^{46}$

\section{SOCKetT's "DEfence” AND The PERVERSITY OF THE COMMITTEE'S DECISION}

Sockett offered two explanations for his conduct. The first I shall term the "Sidon" defence, according to which Sockett did what he did because Sidon, either expressly or by some other more mysterious means, ${ }^{47}$ approved of his conduct, and because it was proper, in the circumstance, for Sockett, the lawyer, to rely on Sidon the bureaucrat. The second I shall dub the "higher purpose/innocent motive" defence, according to which, even had he no such approval from Sidon and even if, in consequence, his conduct were to be found blameworthy, he should yet somehow be relieved because his motivation in pursuing his conduct was part of "his professional philosophy, which obliges him to help the underdog" 48 and because, in and through his conduct regarding the trust funds of First Nations minors, he was following this blameless philosophy and helping the underdog. I shall consider each, though the second in greater depth since, in my view, everything that ultimately matters in the decision in Sockett turns on the Committee's approving of and involving itself and the Law Society in the perverse paternalism of this proposal.

\section{A. THE "SIDON" DEFENCE}

Despite expressing very early along in the piece "considerable interest" in "the fact there are no written guidelines governing what use could be made of the accessed

Ibid. at 31 . Section $78(5)$ reads:

Notwithstanding subsections (1) to (3). if. following their respective hearing under this Division, the Hearing Committee or the panel of benchers is of the opinion that there are reasonable and probable grounds to believe that the member has committed a criminal offence. the Hearing Committee or the panel. as the case may be. shall direct the Executive Director to send a copy of the hearing record to the Minister.

th Ibid.

47 Sockett testified on cross-examination that Sidon "couch[ed] his terms" and. on questioning from the Committee. that Sidon was "speaking in code" (ibid. at 19). 
funds," ${ }^{, 49}$ and despite devoting a great deal of its Report to the matter of what Sidon did or did not indicate to Sockett and what, in consequence, Sockett did or did not understand from Sidon, in the final analysis the Committee decided that the matter mattered not, and it expressed its dissatisfaction with Sockett's "attempts to justify his actions" on this basis. ${ }^{50}$ The Committee was, of course, quite right in this: even if Sidon had expressly told Sockett that he could do what he did, that would not relieve Sockett, who, as a member of the society of lawyers, was burdened with an independent and anterior duty to act lawfully. And honouring that duty depended not at all on any view Sidon may or may not have had of the requirements of the law governing the matter. Which is to say, what was at issue was Sockett's fitness, as a member, and not Sidon's competence as a bureaucrat. Unhappily, the Committee's conclusion does not rely on anything as clear and as necessary as fitness, but instead sits awkwardly in a cloud of premises, most evidentiary and the rest hortatory. Were this not the case, the Committee could, in my view, easily have found Sockett guilty of incompetence in the matter since it did find, contrary to his evidence that "he was very familiar with s. 52 of the Indian Act," research regarding his interpretation," $\$ 2$ that his "interpretation of the relevant section ... was not a considered or informed one, ${ }^{, 53}$ and that, in consequence, he had not done what "might be expected of a lawyer to determine whether or not he was entitled to do as he did." 54

\section{B. The "Higher PuRpose/InNocent Motive" Defence}

The Committee thought it should hear from witnesses ${ }^{55}$ who "had no personal knowledge of the events," 56 because it thought they could provide "contextual evidence"s7 important to the matter before it. And it thought this because it took seriously Sockett's proposal that the significance of a lawyer's violation of the obligations that define lawyerly office ought properly to be measured in terms of the lawyer's motive in violating those obligations..$^{58}$ In consequence, the Committee took care in characterizing the socio-economic and cultural conditions prevailing in First Nations communities, ${ }^{59}$ and in qualifying Sockett's conduct $^{60}$ as a decision "compelled" by those conditions, at once sorry socially" and attractive

lbid. at 8 .

Ibid. at 30 .

Ibid. at 16 .

Ibid. at 19.

lbid. at 25 .

lbid.

For the identity of these "context" witnesses, see supra note 20.

Report. supra note 2 at 5.

lbid. at 20.

Indeed. this proposal was Sockett's counsel's first argument: "Counsel for the Member emphasized the importance of the Committee's finding that the Member was genuinely motivated to help those minors on whose behalf he assisted in accessing their trust funds" (ibid. at 28).

lbid. at II, 12, 20-21.

lbid. at 12, 14, 15, 18, 24, 26, 30 .

Ibid. at 12. 
culturally, ${ }^{63}$ by one philosophically ${ }^{64}$ committed lawyer, to abandon his lawyerly obligations in service to a greater social good. And it was in terms of those two characterizations, permitted by the allowance of this third type of evidence - evidence that went neither to the lawyer's character or conduct nor to his competence, but to the socio-cultural condition and identity of his clients - that the Committee wove its remarkable tale of the propriety of the sanction it levied against Sockett. As put by the Committee, "it is appropriate to distinguish between the Member's conduct and others who have acted fraudulently or misappropriated funds primarily for their personal gain." ${ }^{65}$ Which is to say, the basis for the Committee's distinguishing Sockett's conduct from the conduct of other lawyers who commit fraud is that, in its view, he acted with higher purpose as regards a culturally different and socially and economically deprived class of clients.

As indicated at the outset, I aim to impeach the Committee's decision as a perversion of responsible professional self-government. This impeachment will depend on making out the decision's perversity on three separate grounds: namely, that it is perverse on the facts; that, even were it not perverse factually, it would remain perverse in terms of legal morality because the paternalism it endorses and expresses differentiates between what is owed by lawyers to their clients and to their profession and the public more generally, in terms here of the racial and/or social and cultural character of the client; that, even were the decision not perverse in either of these ways, it would remain perverse in terms of the requirement of proportionality, and inasmuch as it fits the punishment to the offence only by unforgivably diminishing the harm caused by Sockett's defalcation. I shall deal briefly with each ground.

\section{PERVERSE ON THE FACTS}

In America especially, what is known as "cause lawyering" has become a popular fancy among a growing cadre of academic lawyers and not a few practicing lawyers. Cause lawyering has been described in the following fashion:

[C]ause lawyers ... deploy their legal skills to challenge prevailing distributions of political, social, economic. and/or legal values and resources. Cause lawyers choose clients and cases in order to pursue their own ideological and redistributive projects. And they do so, not as a matter of technical competence, but as a matter of personal engagement. ${ }^{66}$

Ibid. at 20: the "very troubling social conditions on these reserves, manifested by widespread poverty. high youth suicide rates, addiction problems. related legal problems and general despair." Ibid: "a culturally entrenched concept of sharing in which it is honourable to share with others what you have to the point of giving away all of one's property"; and at II: "an extended family concept as being an integral part of life on the reserves."

Ibid. at 12.

Ibid. at 29.

A. Sarat \& S. Scheingold, "Introduction" in A. Sarat \& S. Scheingold, eds., Cause Lavyering and the State in a Global Era (Oxford: Oxford University Press, 2001) I at 13. 
Now, whatever else may be said of the view of lawyering that follows from this ${ }^{67}-$ the view, namely, that lawyering may properly be about "achiev[ing] greater social justice - both for particular individuals ... and for disadvantaged groups"68 - it can be said that none of the proponents of that view commends the violation of law or of a lawyer's obligation as practice proper to the lawyer's service to social justice.

So, neither Sockett's behaviour nor the Committee's decision with respect to his behaviour can find shelter in any standing conception of lawyering, even an unusual one such as "cause lawyering." In consequence, both matters have to be considered on the more prosaic level of facts: simply put, is it reasonable, given the facts of Sockett's behaviour, to conclude as did the Committee, that, though Sockett "derived some personal benefit from his actions," the "motivation for his actions ... was primarily to assist those in need"? ${ }^{69}$ Well the facts are these: a) of the $\$ 440,000.00$ Sockett accessed for "those in need," he retained $\$ 217,000$, or $49.3 \%$, in fees; and, on the more retail level of the camel-breaking incident that compelled him "to relax [his] own rules on what [he] was prepared to do with these youths,"70 namely, "his increasing concern about loan sharks who were operating in the Wetaskiwin area and who were preying on minors prior to them receiving their trust funds upon turning $18, " 11$ b) when Sockett levied fees for no service other than accessing the trust accounts of minors, on the evidence offered to the Committee, he charged, on occasion at least, fees up to $35 \%$ of the amount accessed. ${ }^{72}$ On the same evidence, the "loan sharks" were "charging interest rates approaching $40 \% . "{ }^{73}$

\section{PERVERSE MORALLY}

Even, however, if none of this were the case as a matter of fact - and even, indeed, had Sockett rendered the services he did pro bono publico - his behaviour would remain violative of lawyerly office, and the Committee's decision with respect to his behaviour would remain perverse. So far as the quality of his conduct under these assumed circumstances is concerned, suffice it to say that pro bono practice does not provide a lawyer license to practice incompetently or unethically.

The more important matter is the second: even were the matter of fees levied to be put aside, the Committee's decision would remain perverse because it would yet grievously offend legal morality. Let me briefly explain.

And much could be said, not least that cause lawyers use their clients for their own causes in a fashion and to an extent that abandons the basis from which arises all of the obligations that lawyers are commonly thought to owe to clients - that the client is the end beyond which there are no other ends.

C. Menkel-Meadow. "The Causes of Cause Lawyering" in Sarat \& Scheingold. supra note 66 at 37.

Report, supra note 2 at 30.

lbid. at 15 .

Ibid. at 15 .

lbid. at 18 .

Ibid. at 18. 
As previously noted, the Committee thought it proper to hear evidence about the cultural and socio-economic circumstances of the First Nations communities in the Hobbema area. Now, what is important for the present point is not the character of that evidence, but its source. The Committee heard from Sockett and his witnesses in this regard, but it did not hear from the clients involved nor from other members of those communities. In consequence, the evidence the Committee received was about Sockett's clients and their cultural and socio-economic circumstances, it was not, even in part, evidence authored by them. ${ }^{74}$ This lacuna is especially telling. For it committed the Committee to constructing, with the aid of Sockett and his "context" witnesses, an identity for the clients and their communities, and with that, it committed its reasoning, not only to a perverse form of paternalism, but also to a view of the client that offends the predicate upon which all else in law and lawyering depends, namely, the moral and legal equality of the legal subject.

Paternalism exists not only where one presumes to determine what is best for another, but also where one presumes to speak on the other's behalf without the other's warrant. ${ }^{75}$ In both cases, paternalism seeks its warrant in the claim that the presumption is in the best interests of the one on whose behalf the determination is being made or the speech is being delivered. Now, the paternalism in the Report, both its source and its content, is perverse inasmuch as its beneficiary is not the class whose autonomy is being diminished - Sockett's clients and, by implication, their communities - but the one who is doing the diminishing, the supposed benefactor, the "surrogate parent," his context witnesses and, above all else, through the Committee's dispensation.

The effect of this paternalism is corrosive of the fundament of legal and political morality, namely, the equality beyond difference that our law ascribes to those who are subject to its rule. ${ }^{77}$ It is also corrosive of lawyer morality, since its effect is to qualify the requirements of lawyerly office according to the differentiated identity of the client. And with this, the whole cloth of fitness, as regards conduct and character and presumably competence as well, is, if not torn asunder, then at least left in tatters.

\section{PERVERSE PROPORTIONS}

The Committee prefaced its decision on sanction with the following statement of its deliberative context:

On this aspect of the decision, Buffalo, supra note 3. quite properly pointed out that "no one from the law society sought any input from band members or the Samson Cree First Nation administration about Sockett's reputation": "He was allowed to bring positive character evidence references and witnesses before the society, but no one from the law society came to us for anything. How is that equitable?"

7. See generally R. Sartorius, ed., Paternalism (Minneapolis: University of Minnesota Press, 1983).

7. Report. supra note 2 at 28.

$7 \quad$ See generally D. Johnston. ed.. Equality (Indianapolis: Hackett. 2000); and J.R. Pennock \& J.W. Chapman, eds.. Equality: NOMOS IX (New York: Atherton Press, 1967). 
In the circumstances of this case, the Committee finds its task to be a difficult one because, on the one hand, it has to weigh the seriousness of the conduct and the large number of incidents involved and, on the other hand, it has to consider the Member's unblemished record over many years of practice, the motivation for his actions and the strong support he has received from members of the legal community and the community at large. ${ }^{78}$

Counsel for the Law Society attempted to ease the Committee's burden by submitting that Sockett should be disbarred because he was shown to be unfit for office on grounds, inter alia, that his "conduct was in violation of the fundamental principles of integrity and trustworthiness that are essential to maintain the standing of the legal profession."' For his part, Sockett's counsel submitted, inter alia, that "the Committee's finding that the Member was genuinely motivated to help those minors on whose behalf he assisted in accessing their trust funds" was fundamentally important, and that "there was no evidence before the Committee that Mr. Sockett was providing a disservice to his aboriginal clients in the sense that he was doing something that they did not want him to do." ${ }^{80}$ Counsel, that is, argued harm - Dixon the harm caused to the standing of the profession, and Davidson, the absence of harm to Sockett's clients, on grounds, in equal measure, of their having consented to the fraud and of the Committee's having found his motivation worthy. Though the Committee claims it found Dixon's submission "compelling," 11 her arguments were not found sufficiently compelling to warrant Sockett's disbarment. Indeed, when it came to pronounce its decision on sanction, the Committee declared, contrary to Dixon's submission, that it "believe[d] that the public interest will be well served if the Member is required to serve a lengthy suspension and pay a significant fine, as well as pay the costs of the Hearing, for his misconduct." ${ }^{\text {"82 }}$

I want to suggest that the arguments concerning harm proffered by counsel and, more importantly, the Committee's assessment of "the seriousness of [Sockett's] conduct," ${ }^{33}$ so seriously misapprehend the real and multiple harms caused by his conduct that the sanction finally meted out to Sockett grossly offends any reasonable view of the requirements of proportionality. And the harms are indeed real and multiple and, I should have thought, obvious.

First, there exists the harm to the Government of Canada - not only the harm, as the Committee appears to have found, of being "deprived of the funds" ${ }^{84}$ that Sockett improperly took from the trust accounts held by it as a fiduciary, but also the harm of being rendered vulnerable to possible future litigation on behalf of the minors involved to recover, in whole or in part, the funds lost through Sockett's violation of his office. Second, there is the harm to the minors who have lost that part of their trust taken by Sockett in fees and who have otherwise, in my view, been harmed by the paternalism

$\begin{array}{ll}7 \times & \text { Report, supra note } 2 \text { at } 27 . \\ 7 . & \text { Ibid. at } 27 . \\ x_{1} & \text { Ibid. at } 28 . \\ x 1 & \text { Ibid. at } 29 . \\ x_{2} & \text { Ibid. at } 31 . \\ x_{3} & \text { lbid. at } 27 . \\ & \text { lbid. at } 23 .\end{array}$


exhibited in the first instance by Sockett in his dealings with them, and, unhappily, subsequently endorsed by the Committee in its one-sided characterization of them. Third, there is the harm to the profession occasioned, not just by Sockett's conduct, but also by the Committee's treatment of it. Finally, there is the harm to the public which must be presumed to be sustained when a member of the society of lawyers, who holds an office pledged to the public interest, acts directly against that interest by defrauding the public itself through his acts of defrauding the public's governmental representative.

Retributive justice, wherever and whenever it is meted out, is about vindicating and defending communal values. ${ }^{85}$ Punishment is what the offender is due because he has chosen to violate the values that govern the community of which is a member. We punish an offender by denouncing his conduct and, to make sure he hears this denunciation, and realizes that we take seriously and disown his conduct, we lower his status, we humble him. ${ }^{86}$ And because punishment is a public act, we hope too that others will hear this message, and be either comforted or deterred by it. So viewed, punishment enacts, and acts to maintain, the system of values out of which is woven the fabric of communal life. Punishment, however, cannot work this magic if the censure provided is not proportionate to the offence. A punishment may be disproportionate, and therefore unjust, either because it is too harsh or because it is not harsh enough. I want to submit that Sockett's punishment is unjust because, as measured against the harms that together constitute his offence, it is not harsh enough. If I am right in this, then the Committee's decision not to disbar him serves to weaken, rather than to vindicate and defend, the values which the legal community exists to serve and, through its good faith service, to enact in the public life of our community.

\section{CONCLUSION}

The Sockett matter was the subject of much public debate during the course of the hearing. Indeed, so much was this the case that, when speaking to sanction, Sockett's counsel recommended the fact of "significant media attention" as a factor that ought properly go to mitigation. ${ }^{87}$ Nor have matters changed since the Committee announced its decision and released its Report. To the extent that it has spoken, the First Nations community has condemned both the Committee's decision and its process. ${ }^{88}$ For his part, Law Society President Ken Nielsen, Q.C. has appeared eager to defend both the outcome and the process. "The public," he is reported as opining, "should be 'comforted' by the committee's decisions and the process that produced them": "The

See J.R. Lucas. Responsibility (Oxford: Clarendon Press, 1993) c. 6, "Punishment."

Sockett must be taken to know all of this. since he acted in R. v. Hashem, [1997] A.J. No. 696

(C.A.), online: QL (AJ), in which the Alberta Court of Appeal, in an oral judgment delivered by Fraser C.J.A., emphasized "the need for deterrence and denunciation" in cases of breach of trust and fraud.

Report. supra note 2 at 29.

See, e.g., the comments by Mel Buffalo, supra notes 3 and 74. See also the comments by Lucy Johnson, one of Sockett's "context" witnesses: "Lawyer solicits new business despite pending suspension: Law society gave Ken Sockett 60 days for windup of affairs" Edmonton Journal (13 June 2002) A6. 
committee did a very comprehensive job of hearing all the evidence and they weighed it accordingly. I'm very pleased with the process." ${ }^{89}$

There are, however, indications that not everyone in the legal community shares President Nielsen's panglossian view of matters. If I may judge by my own experience, the Committee's decision has been a topic of wide-spread and unrelenting critical talk among lawyers, at least in Edmonton. And at the October convocation, bencher Larry Anderson, Q.C., chair of the conduct committee, "introduced a standardized hearing committee report form"90 which, though it is not available for distribution, ${ }^{91}$ might signal recognition of the need for the Society to act anew in order better to manage the messy particulars of self-governance.

And need there is. The present Hearing Guide ${ }^{92}$ is clearly inadequate to the task of informed and responsible self-governance on matters of fitness. Nor is the Sockett case the only case concerning which the Society's stewardship of the public interest in these affairs has been questioned. Indeed, twice, only recently, Alberta Courts have criticized the Society's conduct of the management of its affairs. ${ }^{93}$ And, there is, finally, the matter of Sockett's s. 75 appeal to the benchers, and of the exercise of the panel's authority under s. $77(1)(\mathrm{c}) .^{94}$ For all of these reasons, and not least for the last, the Law Society should feel itself duty-bound to act in ways that might improve its stewardship of the fitness of its members. For the reasons I have explored and defended in this comment, a necessary first step to the Society's taking up this obligation is to correct the perversity of the penalty levied against Sockett by the Committee: the panel of benchers that sits in judgment of his appeal must, therefore, both confirm the Committee's finding of guilt and correct its mistake by replacing the present order of suspension with an order of disbarment.

*) Supra note 3.

*) Law Society of Alberta, Benchers' Advisory 77 (November 2002) at 2.

$"$ Telephone communication with the Law Society of Alberta (22 November 2002).

"2 Law Society of Alberta, Hearing Guide, version 1.0 (March 2002).

"See Stinchcombe v. Law Society of Alberta, [2002] A.J. No. 544 (C.A.), online: QL (AJ); and Law Society of Alberta v. Lapointe (judgment unavailable: see "Law society violated paralegal's rights - judge" Edmonton Journal (15 June 2002) B5).

Legal Profession Act, supra note 7, s. 75 (Appeal to Benchers); s; 77(1)(c) (Order by Benchers):

77(1) Within a reasonable time after the conclusion of their appeal hearing under section 76, the Benchers may, in respect of any conduct that resulted in the order of the Hearing Committee under section $72(1)(a)$ or (b), make one or more of the following orders:

(c) where the Benchers confirm the Hearing Committee's finding of guilt, an order confirming or varying the Committee's order under section 72 or replacing it with any other order that the Committee could have made under that section. 